\title{
Epilepsies in Children with 2q24.3 Deletion/Duplication
}

\author{
Akihisa Okumura ${ }^{1}$ Toshiyuki Yamamoto ${ }^{2}$ Hirokazu Kurahashi ${ }^{1}$ Michihiko Takasu ${ }^{1}$
}

${ }^{1}$ Department of Pediatrics, Aichi Medical University School of Medicine, Nagakute, Aichi, Japan

2 Tokyo Women's Medical University Institute for Integrated Medical Sciences, Tokyo, Japan

J Pediatr Epilepsy 2015;4:8-16.
Address for correspondence Akihisa Okumura, MD, PhD, Department of Pediatrics, Aichi Medical University School of Medicine, 1-1 Yazako Karimata, Nagakute, Aichi 480-1195, Japan (e-mail: okumura.akihisa.479@mail.aichi-med-u.ac.jp).

\begin{abstract}
Keywords

- sodium channel genes

- dysmorphic features

- Dravet syndrome

- array comparative genomic hybridization

The chromosome 2 q24.3 region appears to be important in childhood epilepsy and contains three genes encoding a sodium channel, which are involved in the disorder (SCN1A, SCN2A, and SCN3A). There have been several reports indicating an association between epilepsy and 2q24.3 deletion or duplication. Epilepsy phenotypes markedly differ between patients with $2 \mathrm{q} 24.3$ deletion and those with duplication. The majority of patients with 2 q24.3 deletion are characterized by severe epilepsy phenotypes such as Dravet syndrome or Dravet syndrome-like intractable epilepsy, which onsets during infancy. This is particularly applicable to patients with SCN1A deletion. In addition, facial dysmorphism (and other dysmorphic features) is observed in all patients with 2q24.3 deletion-associated epilepsy. SCN1A contributes to epileptogenicity; several other genes involved in the deleted region may also play a role in dysmorphism. In all reported cases, patients with 2q24.3 duplication had neonatal- or infantile-onset epilepsy. Although these patients typically experienced multiple daily seizures, seizures were controlled by the appropriate antiepileptic treatment in the majority of cases. SCN2A and SCN3A were duplicated in all patients and are presumed to contribute to epileptogenicity. Facial or other dysmorphic features were infrequent in patients with 2 q24.3 duplication. Array comparative genomic hybridization should be considered in patients with neonatal- or infantile-onset epilepsy, because information obtained using this method is likely to be instructive in diagnosis, prognostication, and treatment regimen decisions.
\end{abstract}

\section{Introduction}

More than 100 cases of deletions or duplications of the long arm of chromosome 2 have been reported. Deletion and duplication ranges vary markedly among individual patients. The relationship between range of deletion/duplication and phenotype is not well understood, although seizures and facial dysmorphism are observed commonly in patients with 2q21q31 deletions. Array comparative genomic hybridization (CGH) is useful to determine copy number variants (CNVs) and to investigate the relationship between $\mathrm{CNV}$ and

received

September 9, 2014

accepted

September 18, 2014
Issue Theme Epilepsy in Numerical Chromosomal Abnormalities; Guest Editor: Toshiyuki Yamamoto, MD, PhD phenotype. Recent studies using array CGH have provided insight into the genetic origin of the phenotypes of patients with CNV in 2q. The 2q24.3 region has attracted attention because three genes encoding a sodium channel, that is, $S C N 1 A, S C N 2 A$, and $S C N 3 A$, are located within this region. Mutations in SCN1A are an established, major genetic determinant of Dravet syndrome (DS), genetic epilepsy with febrile seizure plus (GEFS + ), and other epilepsies mostly refractory against antiepileptic drugs. ${ }^{1-3}$ Mutations in SCN2A have been reported in patients with DS, GEFS + , benign familial
Copyright $\odot 2015$ by Georg Thieme Verlag KG, Stuttgart · New York
DOI http://dx.doi.org/ 10.1055/s-0035-1554786. ISSN 2146-457X. 
neonatal-infantile seizures (BFNIS), and early onset epileptic encephalopathies (EOEE). ${ }^{4-7}$ Mutations in SCN3A have been detected much less frequently in patients with focal epilepsy. ${ }^{8,9}$ Therefore, CNV in the $2 \mathrm{q} 24.3$ region is also presumed to cause epilepsy and genetic mutations in these sodium channel genes. However, the effects of CNVs on epileptogenicity can differ from those of genetic mutations. In this review, we focus principally on the relationship between epilepsy and 2q24.3 deletion/duplication, on the basis of array CGH analyses.

\section{2q24.3 Deletion and Epilepsy}

\section{Patients with 2q24.3 Deletion: Epilepsy and the Genes Involved}

We identified 18 patients with deletion of at least one gene in the 2 q24.3 region, determined by array CGH (-Table 1). . $^{102}$ Patients with chromosomal aberrations, indicating 2q24.3 deletion, but without array CGH analysis results, were not included. The patients comprised nine females and nine males. Epilepsy was documented in 10 of the cases.

We assigned patients to the following three groups: group A (10 patients [patients $1-5,7,8,11,14$, and 15] with complete or partial SCN1A deletion); group B (three patients [patients 6, 10, and 16] with complete or partial deletion of both SCN2A and SCN3A and no SCN1A deletion); and group C (five patients [patients 9,12,13,17, and 18] with no deletion in $S C N 1 A, S C N 2 A$, or $S C N 3 A$ ). In group A, all but one patient had epilepsy. In contrast, only one patient in group $B$ and no patients in group $C$ had epilepsy. This strongly suggests that SCN1A deletion contributes markedly to epileptogenicity, whereas $S C N 2 A$ and $S C N 3 A$ deletion have a comparatively reduced impact.

Differences in epilepsy prevalence may be explained by differences in the pathogenesis of genetic alterations. For SCN1A, truncation mutations are common in patients with DS or other refractory epilepsies. Zuberi et al ${ }^{23}$ reported that 133 of 273 SCN1A mutations in epilepsy patients were truncating, including 51 nonsense, 43 frameshift, 24 splice site, and 15 gross rearrangements. In addition, Suls et $\mathrm{al}^{24}$ reported no SCN1A mutations in 3 of 11 patients with DS (according to sequencing analysis); this suggests that microdeletions involving the SCN1A gene may be common in DS patients. These data further imply that haploinsufficiency of $S C N 1 A$ can cause severe epilepsy. In contrast, the majority of $S C N 2 A$ mutations are missense. Shi et $\mathrm{al}^{5}$ reported SCN2A mutations in patients with BFNIS, GEFS +, DS, and intractable childhood epilepsy, but only one truncating mutation was observed in a patient with intractable childhood epilepsy. Recent studies indicate that $S C N 2 A$ mutations also occur in EOEE patients. ${ }^{7}$ All of the $S C N 2 A$ mutations in these patients were missense. There have been only two reports of epilepsy associated with SCN3A mutations, both of which were missense. ${ }^{8,9}$ These data suggest that haploinsufficiency is not a major pathomechanism of epilepsy in patients with SCN2A and/or SCN3A aberrations.
Epilepsy Phenotypes Associated with 2q24.3 Deletion

Epilepsy phenotypes differ according to the gene deleted (-Table 2). Epilepsy was relatively severe in nine patients with SCN1A deletion (patients 1-5, 7, 8, 11, and 15), irrespectively of the involvement of a wide variety of other genes. The age of onset of epilepsy ranged between 8 weeks and 9 months, and was $<6$ months in seven of the patients. Four patients (patients 1-3 and 5) were diagnosed with DS. The first three patients experienced multiple types of seizures, such as myoclonic, generalized clonic, and complex partial seizures. Seizures were also prolonged, indicative of the typical DS phenotype. ${ }^{10}$ The final patient (patient 5) had polymorphic seizures including atonic, hypomotor (with apnea), and clonic seizures, followed by apnea and spasmlike seizures. ${ }^{12}$ Ictal electroencephalography (EEG) revealed multiple seizure foci; the authors tentatively diagnosed infant malignant migrating partial seizures. However, this diagnosis was revised, with the authors instead describing an epileptic encephalopathy that resembled DS, subsequent to the patient's death from refractory status epilepticus. ${ }^{12}$ The other five patients also had severe epilepsy, characterized by polymorphous seizures. Status epilepticus or prolonged seizures, typically provoked by fever, were documented in three cases (patients 4, 7, and 11); myoclonic seizures or myoclonic jerks were also observed in three patients (patients 4, 7, and 8). These features are similar to those of DS; however, DS was not diagnosed. Seizures in these patients were very frequent and highly refractory to vigorous antiepileptic treatment. These results indicate that SCN1A deletion can cause DS or infantile epileptic encephalopathy with DS-like manifestations, as well as genetic mutations in the SCN1A gene.

The interictal EEGs of these nine patients were characterized by nonspecific abnormalities. Background abnormalities, indexed principally by slowed activity, were described in seven cases; generalized or multifocal epileptiform discharges were also described in seven cases and photosensitivity in three cases. These EEG findings were consistent with DS. $^{25}$

It is notable that three of the SCN1A patients died. Patient 5 died following a refractory status epilepticus, as mentioned above; patient 11 died at 15 years of age while in hospice care; and patient 15 died at 16 months of age while sleeping, suggesting sudden unexpected death in epilepsy. It is well known that DS is associated with significant mortality, and that death may occur at any age. ${ }^{26}$ The mortality rate of DS is between 14 and $20 \%{ }^{26-28}$ Death of DS patients is usually associated with status epilepticus or infection, or is otherwise sudden and unexpected. Our recent study demonstrated that acute encephalopathy occasionally presents in DS, and it resulted in the death of 4 of 15 patients. ${ }^{29}$ It is important to be aware that patients with SCN1A deletion are at risk for sudden and unexpected death even when they are not diagnosed with classical DS.

In contrast to patients with SCN1A deletion, epilepsy was mild and self-limiting in the female patient 10 with SCN2A and SCN3A deletions. ${ }^{17}$ The parents of patient 10 reported that she had a 3- to 4-month history of "zone out," absence, and "shiver-like" episodes at 1 year of age, and further that 


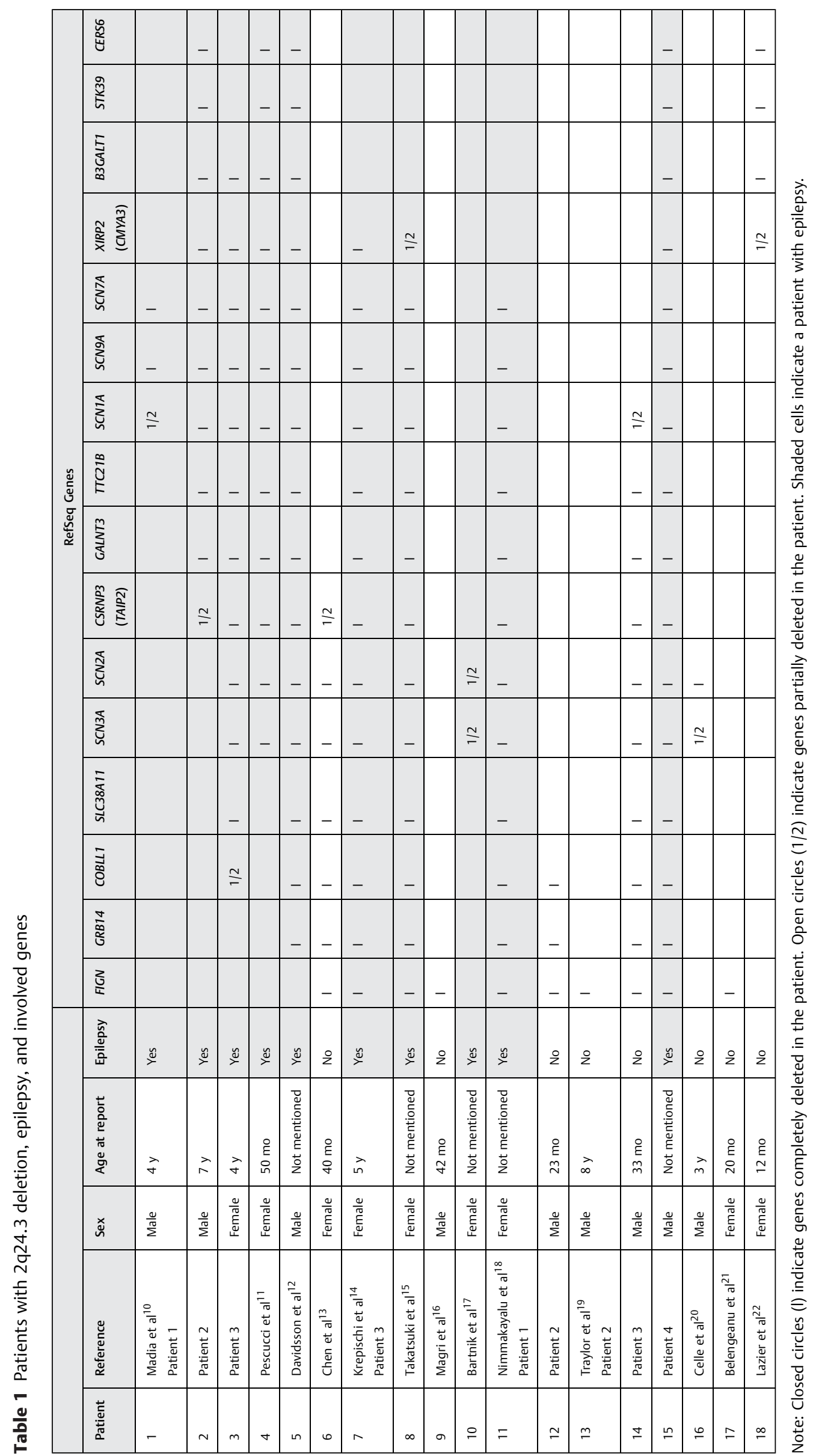


Table 2 Characteristics of epilepsy in patients with 2q24.3 deletion

\begin{tabular}{|c|c|c|c|c|c|c|c|}
\hline Patient & Reference & $\begin{array}{l}\text { Age at } \\
\text { onset }\end{array}$ & Seizure types & Specific diagnosis & Electroencephalography & $\begin{array}{l}\text { Magnetic resonance } \\
\text { imaging }\end{array}$ & Remarks \\
\hline 1 & $\begin{array}{l}\text { Madia et al }{ }^{10} \\
\text { Patient } 1\end{array}$ & $8 \mathrm{mo}$ & $\begin{array}{l}\text { Febrile and afebrile } \\
\text { myoclonic seizures, } \\
\text { sometimes followed by } \\
\text { generalized clonic seizures, } \\
\text { absence seizures }\end{array}$ & Dravet syndrome & $\begin{array}{l}\text { Slowed background activity, } \\
\text { high-voltage generalized } \\
\text { spike and waves, } \\
\text { photosensitivity. }\end{array}$ & Normal & - \\
\hline 2 & Patient 2 & $5 \mathrm{mo}$ & $\begin{array}{l}\text { Prolonged massive } \\
\text { myoclonic or hemiclonic } \\
\text { seizures }\end{array}$ & Dravet syndrome & $\begin{array}{l}\text { Slowed background activity, } \\
\text { high-voltage generalized } \\
\text { spike and waves, } \\
\text { photosensitivity. }\end{array}$ & Normal & - \\
\hline 3 & Patient 3 & $4 \mathrm{mo}$ & $\begin{array}{l}\text { Febrile and afebrile } \\
\text { myoclonic seizures either } \\
\text { focal or massive, complex } \\
\text { partial seizures }\end{array}$ & Dravet syndrome & $\begin{array}{l}\text { Slowed background activity, } \\
\text { focal or generalized spike } \\
\text { and waves }\end{array}$ & Mild ventricular dilation & - \\
\hline 4 & $\begin{array}{l}\text { Pescucci } \\
\text { et al }{ }^{11}\end{array}$ & $3 \mathrm{mo}$ & $\begin{array}{l}\text { Polymorphic with both focal } \\
\text { and generalized seizures, } \\
\text { prolonged severe seizures } \\
\text { and status epilepticus, } \\
\text { sporadic myoclonic jerks }\end{array}$ & Not mentioned & $\begin{array}{l}\text { Slow background, multifocal } \\
\text { spikes/spike and waves }\end{array}$ & $\begin{array}{l}\text { Ventricular dilation, diffuse } \\
\text { atrophy, incomplete white } \\
\text { matter myelination }\end{array}$ & - \\
\hline 5 & $\begin{array}{l}\text { Davidsson } \\
\text { et } \mathrm{al}^{12}\end{array}$ & $8 w k$ & $\begin{array}{l}\text { Atonic seizures, hypomotor } \\
\text { seizures with apnea, clonic } \\
\text { seizures followed by versive } \\
\text { movement and apnea, and } \\
\text { spasm-like seizures followed } \\
\text { by apnea }\end{array}$ & Dravet syndrome & $\begin{array}{l}\text { Multifocal independent } \\
\text { spike and waves }\end{array}$ & $\begin{array}{l}\text { Mild ventricular dilation, } \\
\text { myelination delay }\end{array}$ & $\begin{array}{l}\text { Died after a } \\
\text { refractory status } \\
\text { epilepticus (age } \\
\text { at death is not } \\
\text { described). }\end{array}$ \\
\hline 7 & $\begin{array}{l}\text { Krepischi } \\
\text { et al }{ }^{14} \\
\text { Patient } 3\end{array}$ & $2 \mathrm{mo}$ & $\begin{array}{l}\text { Absence seizures, } \\
\text { generalized tonic seizures, } \\
\text { myoclonic seizures, epileptic } \\
\text { spasms, febrile prolonged } \\
\text { seizures }\end{array}$ & Not mentioned & $\begin{array}{l}\text { Diffuse disorganization, } \\
\text { multifocal spikes/slow- } \\
\text { waves, photosensitivity }\end{array}$ & Normal & - \\
\hline 8 & $\begin{array}{l}\text { Takatsuki } \\
\text { et } \mathrm{al}^{15}\end{array}$ & $3 \mathrm{mo}$ & $\begin{array}{l}\text { Generalized tonic clonic } \\
\text { seizures, continuous } \\
\text { myoclonic jerks }\end{array}$ & Not mentioned & Not mentioned & Not mentioned & - \\
\hline 10 & Bartnik et al ${ }^{17}$ & Uncertain & $\begin{array}{l}\text { Zone out, absent, or } \\
\text { shiver-like episodes }\end{array}$ & Not mentioned & $\begin{array}{l}\text { Generalized abnormal } \\
\text { electroencephalography, } \\
\text { not clearly epileptiform }\end{array}$ & Not mentioned & $\begin{array}{l}\text { Seizures resolved } \\
\text { spontaneously }\end{array}$ \\
\hline 11 & $\begin{array}{l}\text { Nimmakayalu } \\
\text { et al } \\
\text { Patient } 1\end{array}$ & $9 \mathrm{mo}$ & $\begin{array}{l}\text { Brief startle responses } \\
\text { progressing to tonic-clonic } \\
\text { episodes, prolonged severe } \\
\text { seizures and status } \\
\text { epilepticus }\end{array}$ & Not mentioned & Grade II dysrhythmia & $\begin{array}{l}\text { Myelination delay, mild } \\
\text { ventricular dilation, cortical } \\
\text { atrophy }\end{array}$ & $\begin{array}{l}\text { Died at } 15 \text { years } \\
\text { of age in hospice } \\
\text { care }\end{array}$ \\
\hline 15 & $\begin{array}{l}\text { Traylor et al } \\
\text { Patient } 4\end{array}$ & $11 \mathrm{wk}$ & $\begin{array}{l}\text { Staring with a jerking of } \\
\text { extremities and nystagmoid } \\
\text { movements preceded by } \\
\text { crying }\end{array}$ & Not mentioned & $\begin{array}{l}\text { Slow background pattern, } \\
\text { multifocal sharp waves }\end{array}$ & Chiari I malformation & $\begin{array}{l}\text { Died at } \\
16 \text { months of age } \\
\text { while asleep }\end{array}$ \\
\hline
\end{tabular}

the episodes resolved spontaneously without medication. The clinical course and seizure semiology of this patient were similar to those of benign infantile epilepsy. ${ }^{30,31}$ The patient had generalized abnormal EEG, but this was not obviously epileptiform. Detailed information regarding EEG abnormalities was not provided.

\section{Developmental and Other Neurological Symptoms}

All patients with SCN1A deletion were characterized by developmental delay, and at least six of the patients had severe developmental delay ( - Table 3 ). Autistic features were reported in three cases (patients 3-5). Developmental delay occurs in the large majority of DS patients. ${ }^{26}$ Several authors also report that autism spectrum disorders are not uncommon in DS patients. ${ }^{26,32}$ Recent genetic studies that used whole-exome sequencing for parent-child trios exhibiting sporadic autism spectrum disorders suggested that SCN1A might be a genetic determinant of autism spectrum disorders. ${ }^{33,34}$ An experimental study demonstrated that mice with SCN1A haploinsufficiency exhibited autism-like behavioral abnormalities such as hyperactivity, stereotyped behaviors, social interaction deficits, and impaired contextdependent spatial memory. ${ }^{35}$

It is notable that patient 10 , who had SCN2A and SCN3A deletions, was also characterized by severe developmental delay, autistic features, and neurological symptoms, such as hypotonia, bipolar disorder, and ocular motor apraxia, despite the fact that epilepsy was comparatively mild and self-limited. It is also of note that the other two patients with SCN2A and SCN3A deletions (patients 6 and 16) had autism spectrum disorders but no seizures. ${ }^{13,20}$ Several genetic studies that used whole-exome sequencing and whole-genome sequencing have indicated that SCN2A might be a causal factor in autism spectrum disorders. $^{36,37}$ The role of $S C N 3 A$ in autism remains to be clarified. 
12 2q24.3 Deletion/Duplication Okumura et al.

Table 3 Development, other neurological symptoms, and dysmorphic features in patients with 2q24.3 deletion

\begin{tabular}{|c|c|c|c|c|c|}
\hline Patient & Reference & Development & $\begin{array}{l}\text { Other neurological } \\
\text { symptoms }\end{array}$ & Facial dysmorphism & Other symptoms \\
\hline 1 & $\begin{array}{l}\text { Madia et al }{ }^{10} \\
\text { Patient } 1\end{array}$ & Delayed & Not mentioned & $\begin{array}{l}\text { Bulbous nose, bow-shaped } \\
\text { mouth, hypotonic face }\end{array}$ & Not mentioned \\
\hline 2 & Patient 2 & Delayed & $\begin{array}{l}\text { Mild generalized hypo- } \\
\text { tonia, uncoordinated } \\
\text { gait }\end{array}$ & $\begin{array}{l}\text { Down-slanting palpebral fis- } \\
\text { sures, low-implanted ears, } \\
\text { broad nasal bridge }\end{array}$ & Not mentioned \\
\hline 3 & Patient 3 & $\begin{array}{l}\text { Severely delayed, } \\
\text { autistic features }\end{array}$ & $\begin{array}{l}\text { Clumsy gait, mild gen- } \\
\text { eralized hypotonia }\end{array}$ & $\begin{array}{l}\text { Bitemporal narrowing, fron- } \\
\text { tal bossing, tubular nose, } \\
\text { anterior open bite }\end{array}$ & $\begin{array}{l}\text { Cleft palate, central } \\
\text { precocious puberty }\end{array}$ \\
\hline 4 & $\begin{array}{l}\text { Pescucci } \\
\text { et } \mathrm{al}^{11}\end{array}$ & $\begin{array}{l}\text { Severely delayed, } \\
\text { autistic features }\end{array}$ & $\begin{array}{l}\text { Sleep disturbance with } \\
\text { breath holding }\end{array}$ & $\begin{array}{l}\text { Hypotelorism, down-slant- } \\
\text { ing palpebral fissures, long } \\
\text { eye lashes, ptosis, high nasal } \\
\text { bridge with large nose, thick } \\
\text { helices and ear lobule, mild } \\
\text { micrognathia, cupid bow } \\
\text { mouth }\end{array}$ & $\begin{array}{l}\text { Cleft palate, gastro- } \\
\text { esophageal reflux, hand } \\
\text { and foot anomalies, } \\
\text { failure to thrive }\end{array}$ \\
\hline 5 & $\begin{array}{l}\text { Davidsson } \\
\text { et al }{ }^{12}\end{array}$ & $\begin{array}{l}\text { Severely delayed, } \\
\text { autistic features }\end{array}$ & $\begin{array}{l}\text { Hypotonia, brisk tendon } \\
\text { reflexes }\end{array}$ & $\begin{array}{l}\text { Small eyes, slight bilateral } \\
\text { ptosis, micrognathia, low } \\
\text { set small ears }\end{array}$ & $\begin{array}{l}\text { Cleft palate, high anal } \\
\text { atresia, atrial septal } \\
\text { defect, pansynostosis, } \\
\text { syndactyly }\end{array}$ \\
\hline 7 & $\begin{array}{l}\text { Krepischi } \\
\text { et al }{ }^{14} \\
\text { Patient } 3\end{array}$ & Severely delayed & Swallowing difficulty & $\begin{array}{l}\text { Micro/brachycephaly, thin } \\
\text { nose with depressed and } \\
\text { broad nasal bridge, ante- } \\
\text { verted nares, short philtrum }\end{array}$ & $\begin{array}{l}\text { Hypothyroidism, ta- } \\
\text { pered fingers and } \\
\text { anteriorly displaced } \\
\text { anus, left eye iris } \\
\text { coloboma, right eye } \\
\text { choroid, and retina } \\
\text { coloboma }\end{array}$ \\
\hline 8 & $\begin{array}{l}\text { Takatsuki } \\
\text { et } \mathrm{al}^{15}\end{array}$ & Delayed & Generalized hypotonia & $\begin{array}{l}\text { Thick arched eyebrows, } \\
\text { upslanting palpebral fis- } \\
\text { sures, long eyelashes, flat } \\
\text { nasal bridge, short nose, } \\
\text { long philtrum, small mouth, } \\
\text { micrognathia, low-set ears }\end{array}$ & $\begin{array}{l}\text { Pulmonary emphysema, } \\
\text { fetal growth retardation }\end{array}$ \\
\hline 10 & Bartnik et al ${ }^{17}$ & $\begin{array}{l}\text { Severely delayed, } \\
\text { autistic features }\end{array}$ & $\begin{array}{l}\text { Hypotonia, bipolar dis- } \\
\text { order, ocular motor } \\
\text { apraxia }\end{array}$ & $\begin{array}{l}\text { Short palpebral fissures, } \\
\text { mild dental crowding, short } \\
\text { neck }\end{array}$ & Central obesity \\
\hline 11 & $\begin{array}{l}\text { Nimmakayalu } \\
\text { et al }{ }^{18} \\
\text { Patient } 1\end{array}$ & Severely delayed & $\begin{array}{l}\text { Hypotonia, microcepha- } \\
\text { ly, feeding difficulty, } \\
\text { irritability, hypoplastic } \\
\text { optic nerves }\end{array}$ & $\begin{array}{l}\text { Narrow palpebral fissures, } \\
\text { deep set eyes, full cheeks, } \\
\text { small mandible, prominent } \\
\text { lateral palatine ridges, } \\
\text { prominent frenulum } \\
\text { between upper central } \\
\text { incisors, tented upper lip } \\
\text { with downturned corners of } \\
\text { mouth, bitemporal narrow- } \\
\text { ing, short nose with bulbous } \\
\text { tip, dimple at the end of the } \\
\text { nose }\end{array}$ & $\begin{array}{l}\text { Fetal growth retarda- } \\
\text { tion, gastroesophageal } \\
\text { reflux, poor growth, } \\
\text { short sternum, small } \\
\text { hands short slender } \\
\text { tapered fingers }\end{array}$ \\
\hline 15 & $\begin{array}{l}\text { Traylor et al }{ }^{19} \\
\text { Patient } 4\end{array}$ & Severely delayed & Chiari I malformation & $\begin{array}{l}\text { Small downslanting palpe- } \\
\text { bral fissures, posteriorly } \\
\text { rotated ears, uveal } \\
\text { coloboma, coloboma of the } \\
\text { choroid and retina }\end{array}$ & $\begin{array}{l}\text { Fetal growth retarda- } \\
\text { tion, wide-spaced } \\
\text { nipples, chordee of } \\
\text { penis, brachydactyly, } \\
\text { single transverse palmar } \\
\text { crease, bridged palmar } \\
\text { crease, craniosynosto- } \\
\text { sis, failure to thrive }\end{array}$ \\
\hline
\end{tabular}

\section{Dysmorphic Features}

All patients with 2q24.3 deletion were characterized by various dysmorphic features, and facial dysmorphism was present in all cases. Abnormalities of the nose $(n=7)$, mouth $(n=6)$, eyes $(n=5)$, and ears $(n=5)$ were observed. Other manifestations of dysmorphism were noted in eight patients as follows: hand/foot abnormalities $(n=4)$, cleft palate $(n=3)$, fetal growth retardation $(n=3)$, and failure to thrive $(n=2)$. Dysmorphic features due to SCN1A mutations are unusual in DS patients. When dysmorphic features are present in DS patients or in other infantile refractory epilepsies, array CGH can be used to determine the cause of epilepsy. Dysmorphism in patients with 2q24.3 deletion will differ according to the genes deleted (-Table $\mathbf{3}$ ). 


\section{2q24.3 Duplication and Epilepsy}

\section{Epilepsy Associated with 2q24.3 Duplication}

To date, 10 cases of 2q24.3 duplication (6 sporadic patients and 1 family; 3 males and 7 females), as indicated by array $\mathrm{CGH}$, have been reported (-Table 4). ${ }^{38-43}$ All patients had neonatal- or infantile-onset epilepsy. $S C N 2 A$ and $S C N 3 A$ were part of the duplicated region in all patients; SCN1A was involved in all but one case (-Table 4). However, the clinical features did not differ according to the presence or absence of SCN1A duplication. Therefore, epilepsy in patients with 2 q24.3 duplication is apparently attributable to an increase in the number of SCN2A and SCN3A copies.

Epilepsy phenotypes are relatively similar among patients with 2q24.3 duplication (-Table 5), although the region of duplication differs markedly among patients. Onset occurred during the neonatal period in seven cases (patients 19-22, 24 , 26,27 ) and within the first 3 months of life in the remaining three patients (patients 23, 25, 28). The most prevalent seizure types were focal followed by generalized tonic-clonic and myoclonic seizures; spasms were also observed in several patients. A cluster of seizures was observed frequently, but status epilepticus was not noted in any patients.

Interictal EEGs were abnormal in eight of the nine patients for whom information was available. Focal or generalized epileptiform discharges were reported frequently. These nonspecific EEG abnormalities are observed frequently in neonatal-onset or early-infantile-onset epilepsy patients. Magnetic resonance imaging (MRI) data were obtained from seven patients. Although one patient had mild hypoplasia of the corpus callosum, the others were not characterized by any MRI abnormalities.

The most notable feature in patients with 2q24.3 duplication was a relatively favorable seizure outcome compared with 2 q24.3 deletion patients. At the time of report, only one patient failed to achieve seizure freedom, and medication had been discontinued in seven patients. The antiepileptic drugs presumed to be effective for epilepsy include phenobarbital, phenytoin, vigabatrin, valproate, carbamazepine, and oxcarbazepine. The data indicate that antiepileptic treatment should be considered particularly in neonatal-onset to early-infantile-onset epileptic patients with 2q24.3 duplication. Seizure cessation can improve the quality of life in such patients significantly, although the efficacy of drug treatment varies among individual patients.

These features are not consistent with the literature regarding the established types of epilepsies in patients with SCN2A mutations. The duration of seizure persistence in these patients was relatively similar to that of BFNIS, a typical epilepsy phenotype related to SCN2A mutations. The response to antiepileptic drugs was less favorable in these patients compared with BFNIS patients. DS and EOEE, which represent other typical epilepsy phenotypes associated with SCN2A mutations, are markedly more refractory than are epilepsies associated with 2q24.3 duplication. Although increased numbers of SCN2A and SCN3A copies are presumed to affect the function of sodium channels, the precise pathomechanism underlying this effect remains to be elucidated.

\section{Developmental and Other Features}

In contrast to seizure outcome, the developmental outcome was not favorable in the majority of the patients. Only one patient did not exhibit any degree of developmental delay. Autistic features were documented in one patient. Other neurological symptoms reported were hypotonia $(n=1)$, mild dystonic movement $(n=1)$, and swallowing difficulty $(n=1)$ (-Table 6).

It is notable that facial dysmorphism was not described in any patient. Sporadic visceral anomalies were present in two patients (congenital anomalies of the kidney and the urinary tract in patient 27 and hypoplastic left heart syndrome in patient 28). The lack of dysmorphic features and specific neurological symptoms implies that $2 \mathrm{q} 24.3$ duplication is difficult to diagnose without the use of array $\mathrm{CGH}$.

\section{A Representative Patient}

Patient 24 has been discussed previously in a patient report. ${ }^{40}$ This female was born at term following an uncomplicated pregnancy. She was the first child of unrelated, healthy parents. The patient exhibited no dysmorphic features but experienced seizures characterized by staring and mild convulsive movements, 10 to 20 seconds in duration, since the third day of life. The patient was admitted to a neonatal intensive care unit at 9 days of age. Physical examination revealed mild hypotonia but was otherwise unremarkable. Head MRI and blood examination, including metabolic screening of amino acids and organic acid analyses, revealed no abnormalities. Interictal EEG revealed markedly abnormal background activity with spiky transients. The patient was treated with phenobarbital and midazolam; seizures were attenuated transiently at 23 days of age. Seizures recurred at 2 months of age, at which time the patient was admitted to our hospital, after which she experienced between 10 and 50 seizures per day. Treatment with phenobarbital and levetiracetam was ineffective. Array CGH analysis was performed at 5 months of age and revealed duplication of 2q24.2q24.3. On the basis of this result, phenobarbital and levetiracetam were substituted for valproate monotherapy; seizures were completely controlled by $50 \mathrm{mg} / \mathrm{kg} /$ day valproate after 6 months of age. Seizures provoked by fever were not documented. The patient remained free of seizures even following valproate discontinuation at 40 months of age. The patient's development was delayed severely. At the final follow-up at 44 months of age, the patient could walk only with support. She could communicate using certain simple words but could not produce two-word sentences. Generalized hypotonia was observed with normal deep tendon reflexes.

\section{Summary}

Epilepsy is a common neurological disorder in patients with 2q24.3 deletion/duplication. Sodium channel genes (i.e., $S C N 1 A, S C N 2 A$, and SCN3A) in this region are highly likely to contribute to epileptogenicity. The fact that both an increase and a decrease in the number of copies of these genes are associated closely with the presence of epilepsy indicates that 

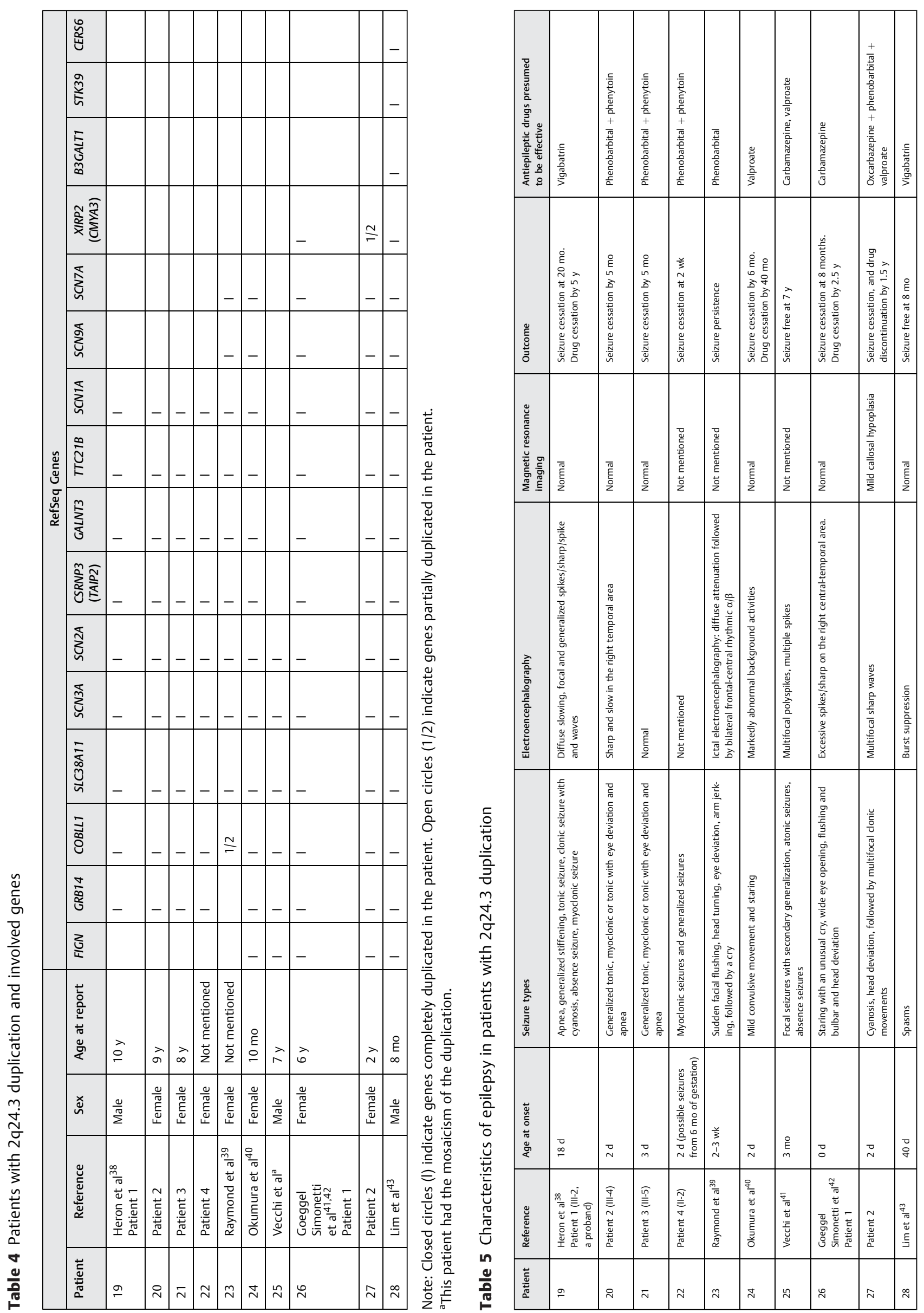
Table 6 Development, other neurological symptoms, and dysmorphic features in patients with 2q24.3 duplication

\begin{tabular}{|c|c|c|c|c|c|}
\hline Patient & Reference & Development & $\begin{array}{l}\text { Other neurological } \\
\text { symptoms }\end{array}$ & $\begin{array}{l}\text { Facial } \\
\text { dysmorphism }\end{array}$ & Other symptoms \\
\hline 19 & $\begin{array}{l}\text { Heron et } \mathrm{al}^{38} \\
\text { Patient } 1 \text { (III-2, a proband) }\end{array}$ & $\begin{array}{l}\text { Delayed, autistic } \\
\text { features }\end{array}$ & None & None & Not mentioned \\
\hline 20 & Patient 2 (III-4) & Delayed & Not mentioned & Not mentioned & Not mentioned \\
\hline 21 & Patient 3 (III-5) & Delayed & Not mentioned & Not mentioned & Not mentioned \\
\hline 22 & Patient 4 (II-2) & Borderline intellect & Not mentioned & Not mentioned & Not mentioned \\
\hline 23 & Raymond et al ${ }^{39}$ & Delayed & Not mentioned & None & Not mentioned \\
\hline 24 & Okumura et al ${ }^{40}$ & Severely delayed & Hypotonia & None & None \\
\hline 25 & Vecchi et $\mathrm{al}^{41}$ & Delayed & Not mentioned & None & Not mentioned \\
\hline 26 & $\begin{array}{l}\text { Goeggel Simonetti } \\
\text { et al } \\
\text { Patient } 1\end{array}$ & Mildly delayed & Not mentioned & Not mentioned & Not mentioned \\
\hline 27 & Patient 2 & Normal & Mild dystonic movement & None & $\begin{array}{l}\text { Fetal growth } \\
\text { retardation, CAKUT }\end{array}$ \\
\hline 28 & Lim et $\mathrm{al}^{43}$ & Delayed & Swallowing difficulty & None & $\begin{array}{l}\text { Hypoplastic left } \\
\text { heart syndrome }\end{array}$ \\
\hline
\end{tabular}

Abbreviation: CAKUT, congenital anomalies of the kidney and the urinary tract.

balance among sodium channel genes is essential for normal brain function and development.

Epilepsy phenotypes differ between patients with 2 q24.3 deletion and those with 2q24.3 duplication. Severe epilepsy phenotypes, such as DS, manifest frequently in patients with 2q24.3 deletion, particularly in those with SCN1A deletion. Dysmorphic features are also common in these patients. In contrast, epilepsy in patients with 2q24.3 duplication is relatively mild; furthermore, cessation of seizures can be achieved in a large majority of such patients. Dysmorphic features are usually absent.

Neonatal- and infantile-period onset epilepsy is common in patients with 2q24.3 deletion/duplication. Array CGH should be considered in such patients, because information obtained using array CGH is useful in the diagnosis, prognostication, and treatment regimen decisions. At present, the number of reported cases of 2q24.3 deletion/duplication is limited. Additional data will likely improve our understanding of epilepsy related to 2q24.3 deletion/duplication.

\section{References}

1 Claes L, Del-Favero J, Ceulemans B, Lagae L, Van Broeckhoven C, De Jonghe P. De novo mutations in the sodium-channel gene SCN1A cause severe myoclonic epilepsy of infancy. Am J Hum Genet 2001; 68(6):1327-1332

2 Wallace RH, Scheffer IE, Barnett S, et al. Neuronal sodium-channel alpha1-subunit mutations in generalized epilepsy with febrile seizures plus. Am J Hum Genet 2001;68(4):859-865

3 Harkin LA, McMahon JM, Iona X, et al; Infantile Epileptic Encephalopathy Referral Consortium.. The spectrum of SCN1A-related infantile epileptic encephalopathies. Brain 2007;130(Pt 3): 843-852

4 Shi X, Yasumoto S, Nakagawa E, Fukasawa T, Uchiya S, Hirose S. Missense mutation of the sodium channel gene SCN2A causes Dravet syndrome. Brain Dev 2009;31(10):758-762
5 Shi X, Yasumoto S, Kurahashi H, et al. Clinical spectrum of SCN2A mutations. Brain Dev 2012;34(7):541-545

6 Heron SE, Crossland KM, Andermann E, et al. Sodium-channel defects in benign familial neonatal-infantile seizures. Lancet 2002; 360(9336):851-852

7 Nakamura K, Kato M, Osaka H, et al. Clinical spectrum of SCN2A mutations expanding to Ohtahara syndrome. Neurology 2013; 81(11):992-998

8 Holland KD, Kearney JA, Glauser TA, et al. Mutation of sodium channel SCN3A in a patient with cryptogenic pediatric partial epilepsy. Neurosci Lett 2008;433(1):65-70

9 Vanoye CG, Gurnett CA, Holland KD, George AL Jr, Kearney JA. Novel SCN3A variants associated with focal epilepsy in children. Neurobiol Dis 2014;62:313-322

10 Madia F, Striano P, Gennaro E, et al. Cryptic chromosome deletions involving SCN1A in severe myoclonic epilepsy of infancy. Neurology 2006;67(7):1230-1235

11 Pescucci C, Caselli R, Grosso S, et al. 2q24-q31 deletion: report of a case and review of the literature. Eur J Med Genet 2007;50(1): 21-32

12 Davidsson J, Collin A, Olsson ME, Lundgren J, Soller M. Deletion of the SCN gene cluster on 2q24.4 is associated with severe epilepsy: an array-based genotype-phenotype correlation and a comprehensive review of previously published cases. Epilepsy Res 2008; 81(1):69-79

13 Chen CP, Lin SP, Chern SR, et al. Array-CGH detection of a de novo $2.8 \mathrm{Mb}$ deletion in $2 \mathrm{q} 24.2->\mathrm{q} 24.3$ in a girl with autistic features and developmental delay. Eur J Med Genet 2010;53(4):217-220

14 Krepischi AC, Knijnenburg J, Bertola DR, et al. Two distinct regions in 2q24.2-q24.3 associated with idiopathic epilepsy. Epilepsia 2010;51(12):2457-2460

15 Takatsuki S, Nakamura R, Haga Y, et al. Severe pulmonary emphysema in a girl with interstitial deletion of 2 q24.2q24.3 including ITGB6. Am J Med Genet A 2010;152A(4):1020-1025

16 Magri C, Piovani G, Pilotta A, Michele T, Buzi F, Barlati S. De novo deletion of chromosome 2q24.2 region in a mentally retarded boy with muscular hypotonia. Eur J Med Genet 2011;54(3): 361-364

17 Bartnik M, Chun-Hui Tsai A, Xia Z, Cheung SW, Stankiewicz P. Disruption of the SCN2A and SCN3A genes in a patient with mental 
retardation, neurobehavioral and psychiatric abnormalities, and a history of infantile seizures. Clin Genet 2011;80(2):191-195

18 Nimmakayalu M, Noble N, Horton VK, et al. 2q24 deletions: further characterization of clinical findings and their relation to the SCN cluster. Am J Med Genet A 2012;158A(11):2767-2774

19 Traylor RN, Dobyns WB, Rosenfeld JA, et al. Investigation of TBR1 Hemizygosity: Four Individuals with 2q24 Microdeletions. Mol Syndromol 2012;3(3):102-112

20 Celle ME, Cuoco C, Porta S, Gimelli G, Tassano E. Interstitial 2q24.3 deletion including SCN2A and SCN3A genes in a patient with autistic features, psychomotor delay, microcephaly and no history of seizures. Gene 2013;532(2):294-296

21 Belengeanu V, Gamage TH, Farcas S, et al. A de novo $2.3 \mathrm{Mb}$ deletion in 2q24.2q24.3 in a 20-month-old developmentally delayed girl. Gene 2014;539(1):168-172

22 Lazier J, Chernos J, Lowry RB. A 2q24.3q31.1 microdeletion found in a patient with Filippi-like syndrome phenotype: a case report Am J Med Genet A 2014;164A(9):2385-2387

23 Zuberi SM, Brunklaus A, Birch R, Reavey E, Duncan J, Forbes GH. Genotype-phenotype associations in SCN1A-related epilepsies. Neurology 2011;76(7):594-600

24 Suls A, Claeys KG, Goossens D, et al. Microdeletions involving the SCN1A gene may be common in SCN1A-mutation-negative SMEI patients. Hum Mutat 2006;27(9):914-920

25 Bureau M, Dalla Bernardina B. Electroencephalographic characteristics of Dravet syndrome. Epilepsia 2011;52(Suppl 2):13-23

26 Genton P, Velizarova R, Dravet C. Dravet syndrome: the long-term outcome. Epilepsia 2011;52(Suppl 2):44-49

27 Akiyama M, Kobayashi K, Yoshinaga H, Ohtsuka Y. A long-term follow-up study of Dravet syndrome up to adulthood. Epilepsia 2010;51(6):1043-1052

28 Oguni H, Hayashi K, Awaya Y, Fukuyama Y, Osawa M. Severe myoclonic epilepsy in infants-a review based on the Tokyo Women's Medical University series of 84 cases. Brain Dev 2001; 23(7):736-748

29 Okumura A, Uematsu M, Imataka G, et al. Acute encephalopathy in children with Dravet syndrome. Epilepsia 2012;53(1):79-86

30 Watanabe K, Okumura A. Benign partial epilepsies in infancy. Brain Dev 2000;22(5):296-300
31 Okumura A, Watanabe K, Negoro T, et al. Long-term follow-up of patients with benign partial epilepsy in infancy. Epilepsia 2006; 47(1):181-185

32 Li BM, Liu XR, Yi YH, et al. Autism in Dravet syndrome: prevalence, features, and relationship to the clinical characteristics of epilepsy and mental retardation. Epilepsy Behav 2011;21(3):291-295

33 O'Roak BJ, Deriziotis P, Lee C, et al. Exome sequencing in sporadic autism spectrum disorders identifies severe de novo mutations. Nat Genet 2011;43(6):585-589

34 O'Roak BJ, Vives L, Girirajan S, et al. Sporadic autism exomes reveal a highly interconnected protein network of de novo mutations. Nature 2012;485(7397):246-250

35 Han S, Tai C, Westenbroek RE, et al. Autistic-like behaviour in Scn $1 \mathrm{a}+/$ - mice and rescue by enhanced GABA-mediated neurotransmission. Nature 2012;489(7416):385-390

36 Sanders SJ, Murtha MT, Gupta AR, et al. De novo mutations revealed by whole-exome sequencing are strongly associated with autism. Nature 2012;485(7397):237-241

37 Jiang YH, Yuen RK, Jin X, et al. Detection of clinically relevant genetic variants in autism spectrum disorder by whole-genome sequencing. Am J Hum Genet 2013;93(2):249-263

38 Heron SE, Scheffer IE, Grinton BE, et al. Familial neonatal seizures with intellectual disability caused by a microduplication of chromosome 2q24.3. Epilepsia 2010;51(9):1865-1869

39 Raymond G, Wohler E, Dinsmore C, et al. An interstitial duplication at 2q24.3 involving the SCN1A, SCN2A, SCN3A genes associated with infantile epilepsy. Am J Med Genet A 2011;155A(4):920-923

40 Okumura A, Yamamoto T, Shimojima K, et al. Refractory neonatal epilepsy with a de novo duplication of chromosome 2q24.2q24.3. Epilepsia 2011;52(7):e66-e69

41 Vecchi M, Cassina M, Casarin A, et al. Infantile epilepsy associated with mosaic 2q24 duplication including SCN2A and SCN3A. Seizure 2011;20(10):813-816

42 Goeggel Simonetti B, Rieubland C, Courage C, et al. Duplication of the sodium channel gene cluster on 2q24 in children with early onset epilepsy. Epilepsia 2012;53(12):2128-2134

43 Lim BC, Min BJ, Park WY, et al. A unique phenotype of 2q24.32q32.1 duplication: early infantile epileptic encephalopathy without mesomelic dysplasia. J Child Neurol 2014;29(2):260-264 